\title{
PENGUATAN LITERASI DI SEKOLAH
}

\author{
Superman $^{1}$, Yulita Dewi Purmintasari ${ }^{2}$, Rini Agustina ${ }^{3}$ \\ ${ }^{1,2}$ Pendidikan Sejarah Fakultas Ilmu Pendidikan dan Pengetahuan Sosial IKIP PGRI Pontianak \\ ${ }^{3}$ Pendidikan Bahasa Indonesia Fakultas Pendidikan Bahasa dan Seni IKIP PGRI Pontianak \\ Jalan Ampera Nomor 88 Pontianak \\ 1'e-mail: namakusuperman@gmail.com
}

\begin{abstract}
Abstrak
Pokok permasalahan yang dialami mitra dalam kegiatan pengabdian ini ialah masih rendahnya minat baca siswa, sarana kegiatan literasi di sekolah masih minim ditandai dengan belum adanya perpustakaan yang representatif. Tujuan dilakukannya pengabdian ini ialah untuk meningkatkan kapasitas serta tata kelola kegiatan literasi di sekolah. Metode yang digunakan ialah dengan pembenahan sarana fisik dan pelatihan tata kelola program GLS. Hasil dari kegiatan pengabdian ini siswa memiliki minat literasi dengan disediakannya pojok literasi di kelas dan dibuatkanya perpustakaan yang memadai bagi siswa untuk belajar di perpustakaan. Adanya pojok literasi dan perpustakaan mendorong terlaksananya Gerakan Literasi Sekolah di SMP Pancasila Sungai Kakap.
\end{abstract}

Kata kunci: literasi, GLS, SMP Pancasila Sungai Kakap

\begin{abstract}
The main problem experienced by partners in this community service activity is the still low interest in reading students, facilities for literacy activities in schools are still minimal, marked by the absence of a representative library. The purpose of this service is to increase the capacity and governance of literacy activities in schools. The method used is to improve physical facilities and GLS program governance training. The results of this community service activity students have an interest in literacy by providing a literacy corner in the classroom and making an adequate library for students to study in the library. The existence of literacy and library corners encourages the implementation of Gerakan Literasi Sekolah in SMP Pancasila Sungai Kakap.
\end{abstract}

Keywords: literacy, GLS, SMP Pancasila Sungai Kakap

\section{PENDAHULUAN}

Literasi merupakan salah satu program prioritas pemerintah untuk tahun 2019. Kemampuan literasi dinilai berperan penting bagi pertumbuhan intelektual dan kompetisi setiap individu di Indonesia. Gerakan Literasi Sekolah (GLS) sebenarnya telah digalakan sejak tahun 2015 sejalan dengan penerbitan Peraturan Menteri Pendidikan dan Kebudayaan Nomor 23 Tahun 2015 tentang Penumbuhan Budi Pekerti.

Demi menyukseskan pembangunan Indonesia di abad ke-21, menjadi keharusan bagi masyarakat Indonesia untuk menguasai enam literasi dasar, yaitu literasi bahasa, literasi numerasi, literasi sains, literasi digital, literasi finansial, 
serta literasi budaya dan kewargaan. Kemampuan literasi ini juga harus diimbangi dengan menumbuhkembangkan kompetensi yang meliputi kemampuan berpikir kritis/ memecahkan masalah, kreativitas, komunikasi, dan kolaborasi.

Sebagai program yang berkesinambungan, GLS telah berkembang melibatkan berbagai kementerian dan hingga tahun 2017 telah menerbitkan buku manual panduan untuk menunjang pelaksanaan program tersebut. Dampak yang signifikan telah dirasakan di beberapa daerah. Hal ini terlihat dari berperan aktifnya pemerintah daerah dengan menerbitkan Peraturan Daerah (Perda), Surat Edaran Kepala Dinas Pendidikan, dan alokasi APBD untuk mendukung pelaksanaan GLS. Namun sayangnya, tidak semua daerah merealisasikan hal tersebut termasuk daerah sasaran program pengabdian yang telah dilaksanakan.

Mitra dalam pengabdian pada masyarakat ini adalah SMP Pancasila yang berlokasi di Pal Sembilan No. 175 Kecamatan Sungai Kakap Kabupaten Kubu Raya Kalimantan Barat. Sekolah ini berdiri sejak tahun 1983 namun beberapa sarana-prasarana masih baru, seperti baru tersedianya ruang perpustakaan dan juga ruang laboratorium. Walaupun perpustakaan yang ada merupakan ruang kecil yang berdampingan dengan ruang laboratorium.

Pada tahun 2017 SMP Pancasila mendapatkan bantuan pembangunan ruang perpustakaan dan beberapa buku dari Dinas Pendidikan dan Kebudayaan Kalimantan Barat. Fasilitas yang baru tersedia di dalam perpustakaan terdapat 6 meja dan 12 kursi serta 1 lemari buku. Pada saat observasi dilakukan, perpustakaan belum bisa digunakan karena masih dalam tahap penataan dan pembenahan ruangan. Koleksi buku yang terbatas serta sempitnya ruang perpustakaan merupakan permasalahan yang dihadapi sekolah.

Perpustakaan sebagai sebuah pusat pengetahuan dan pusat pembelajaran memiliki peran yang sangat penting karena secara ideal di dalamnya tersedia begitu banyak informasi yang dapat digunakan bagi yang bermaksud memiliki keterampilan yang dapat digunakan untuk memproduksi sesuatu yang bernilai ekonomi, dari produk yang sederhana sampai produk yang canggih. Untuk menciptakan perpustakaan yang sedemikian fungsinya harus diatur dengan 
manajemen perpustakaan yang baik. Hal itu juga tentunya belum diterapkan di sekolah tersebut.

Permasalahan lain yang juga dihadapi sekolah adalah belum tersedianya Sumber Daya Manusia (SDM) yang memadai sehingga belum ada upaya perbaikan terkait permasalahan literasi di sekolah. Setelah melihat permasalahan yang ada di SMP Pancasila, GLS dirasa sangat mendesak untuk dikenalkan dan diterapkan.

\section{METODE}

Berdasarkan permasalahan yang dihadapi mitra maka metode dalam pengabdian pada masyarakat dibagi dalam beberapa tahapan. Tahapan pertama sebagai upaya mempersiapkan sarana dan prasarana yang memadai bagi siswa untuk menumbuh kembangkan budaya literasi di sekolah yaitu membenahi perpustakaan yang ada. Kegiatan pembenahan ini bertujuan menciptakan ruang perpustakaan yang menarik dan kondusif bagi siswa. Penambahan koleksi buku bacaan yang menarik juga termasuk ke dalam bagian ini. Untuk memperluas ruang lingkup zona membaca agar tidak hanya terfokus di perpustakaan, pembuatan pojok baca di sudut kelas merupakan bagian dari upaya menyiapkan ruang yang kondusif bagi tumbuh kembang budaya literasi.

Tahapan kedua pelaksanaan pengabdian terfokus pada pemberian motivasi dan pendampingan pengenalan literasi. Pada bagian ini dilaksanakan rangkaian kegiatan seminar dan sosialisasi mengenai literasi. Kegiatan seminar yaitu upaya untuk memotivasi siswa agar minat bacanya meningkat. Kegiatan sosialisasi literasi pula sasarannya ialah guru dan orang tua siswa. Keterlibatan guru dan orang tua siswa diharapkan dapat menunjang tumbuh-kembang budaya literasi di sekolah maupun di rumah. Kegiatan sosialisasi pemberian motivasi dan pendampingan pengenalan literasi berkolaborasi dengan Balai Bahasa Provinsi Kalimantan Barat, Dinas Pendidikan Provinsi Kalimantan Barat, SMP Negeri 2 Pontianak dan Komunitas Kalbar Membaca.

Pemilihan kolabolatror didasarkan pada kebutuhan dan kinerja dari masingmasing kolaborator baik sebagai fasilitator literasi, pendorong kegiatan literasi, 
maupun sebagai unit yang sudah mengimplementasikan gerakan literasi. Balai bahasa dan dinas pendidikan Kalimantan Barat sebagai dua lembaga yang mempunyai tanggung jawab untuk mensosialisasikan dan mendorong gerakan literasi baik di sekolah maupun di masyarakat. SMP Negeri 2 Pontianak menjadi kolaborator dikarenakan sudah mengimplemantasikan gerakan literasi dengan berbagai kegiatan literasi disekolahnya. Sedangkan Komunitas Kalbar membaca merupakan komunitas yang terus bergerak untuk mendorong masyarakat Kalimantan Barat mencintai literasi.

Tahap Ketiga yaitu pelatihan tata kelola perpustakaan. Termasuk di dalamnya ialah pelatihan pemanfaatan perpustakaan online. Kegiatan pelatihan manajemen perpustakaan melibatkan guru dan operator perpustakan di SMP Pancasila Sungai Kakap. Guru menjadi peserta pelatihan dikarenakan sudah sepatutnya seorang guru sebagai bagian dari kunci sukses gerakan literasi sekolah harus mengatahu manajemen perpustakaan sehingga dapat dengan cermat untuk mendorong budaya literasi sekolah. Kegiatan pelatihan berkolaborasi dengan perpustakaan IKIP PGRI Pontianak.

\section{HASIL DAN PEMBAHASAN}

\section{Perpustakaan Sekolah}

Perpustakaan merupakan nadi sekolah yang memberikan ruang untuk menggali informasi pengetahuan sebagai penunjang pendidikan, bukan hanya sekedar ruangan untuk menyimpan buku. Perpustakaan sekolah merupakan koleksi yang diorganisasi di dalam suatu ruang agar dapat digunakan oleh muridmurid dan guru-guru (Solahudin, 2011: 13). Melihat pentingnya perpustakaan diharapkan mampu menjadi tempat yang sangat dinanti kehadirannya oleh warga baik warga sekolah maupun masyarakat secara umum. Keberadaan perpustakaan sesuai dengan SK Mendiknas No. 053/U/2001 tanggal 19 April 2001 tentang Penyusunan Pedoman Standar Pelayanan Minimal Penyelenggaraan Persekolahan pada Tingkat TK, Dasar sampai dengan SMU/SMK, bahwa keberadaan perpustakaan sekolah merupakan syarat dalam standar pelayanan minimal (SPM). 
Hasil yang tercapai kegiatan pengabdian pada masyarakat pada tahap pertama berupa kegiatan fisik yaitu adalah pembenahan perpustakaan. Kegiatan ini mengalami sedikit kendala yaitu ruang perpustakaan yang harus berpindah. Ruang awal yang digunakan adalah ruangan yang berdekatan dengan ruang Labolaturium IPA. Namun, pada saat pelaksanaan dipindahkan ke ruang kosong lain yang lebih luas tapi memerlukan perlakuan ekstra. Ruang yang dijadikan perpustakaan dulunya merupakan ruang komputer yang kondisinya sama sekali tidak terawat, sehingga rencana awal yang hanya membenahi perpustakaan menjadi membuat perpustakan baru. Pembuatan dan pembenahan ruangan perpustakaan yang baru ini memerlukan waktu yang cukup lebih lama dibanding apa yang sudah direncanakan semula. Selain itu dasar pemindahan ruang perputakaan karena ruang perpustakaan lama yang bergabung dengan labolaturium IPA hanya memiliki satu pintu masuk sehingga adanya kekhawatiran pihak sekolah adanya permasalahan dikemudian hari.

Pembenahan perpustakaan dimulai dengan melepas rak-rak bekas, memindahkan barang-barang yang ada di ruangan seperti meja, kursi, monitor tabung dan PC yang tidak terpakai serta menyapu ruangan. Ruang perpustakaan yang digunakan saat ini dulunya merupakan ruang laboraturium komputer sehingga banyak menyisakan perlengkapan komputer yang tidak terpakai dan ruangan dalam keadaan layaknya gudang.

Kegiatan selanjutnya menambal lantai semen yang berlobang dan retak serta membenahi bagian langit-langit ruangan yang sudah mengelupas. Setelah kondisi lantai dan langit-langit memadai baru kemudian dilakukan pembersihan dan pengecatan dinding. Perpustakaan dirancang untuk duduk lesehan. Hal itu agar ruangan perpustakaan senantiasa dalam keadaan bersih ketika dikunjungi. Maka dari itu, kegiatan selanjutnya yaitu memasang karpet, menyediakan rak serta memindahkan buku-buku ke perpustakaan.

Desain perpustakaan tersebut dirancang untuk memberikan rasa aman dan nyaman bagi pembaca, memiliki pencahayaan yang baik, didesain untuk mengakomodasi perabotan yang kokoh, tahan lama dan fungsional, disesain untuk 
menampung populasi seklah secara representatif, didesain agar dapat mengakomodasi progran sekolah dan pembelajaran.

Penyediaan ruang perpustakaan yang memadai dikarenakan Perpustakaan merupakan peran vital dalam lembaga pendidikan, keberadaannya sangat menentukan kualitas dari lembaga pendidikan, perpustakaan sebagai jantung, sehingga hidup matinya sekolah sangat dipengaruhi kesehatan perpustakaan dalam hal ini kuantitas dan kualitasnya (Mubasyaroh, 2016:78). Hal tersebut selaras dengan Undang-Undang No 20 Tahun 2003 tentang Sistem Pendidikan Nasional (SISDIKNAS) bahwa perpustakaan berfungsi mendukung sistem pendidikan nasional.

Perpustakan mendukung terlaksananya gerakan literasi sekolah sebagai pusat literasi. Walaupun pada pelaksanaan kegiatan literasi dapat dilakukan dimana saja tidak harus diperpustakaan. Perpustakaan penjadi sarana pendorong gerakan literasi dikarenakan perpustakaan sekolah bertujuan untuk mninkatkan kemampuan dan minat baca, membantu menulis kreatif, menyediakan sumbersumber informasi, sarana pengembangan pengetahuan secara mandiri dan sebagai sarana hiburan. Selain itu perpustakaan memiliki fungsi edukatif, informatif, reseach dan rekreatif.

Termasuk kedalam aspek penyediaan sarana literasi, di awal kegiatan PKM telah dirancang perpustakaan digital untuk SMP Pancasila Sungai Kakap. Pengadaan perpustakaan digital ini dapat diwujudkan berkat kerjasama IKIP PGRI Pontianak dengan KUBUKU melalui program penyediaan perpustakaan digital secara cuma-cuma. Kesempatan ini tentu saja dimanfaatkan guna menunjang program literasi yang sedang dilaksanakan. Pengadaan perputakaan digital ini mengikuti perkembangan teknologi di era revolusi industri 4.0 yang menjangkaunuga dunia pendidikan. Perpustakaan digital SMP Pancasila ini tersedia di google Playstore yang dapat diunduh dan dibaca koleksi bukubukunya.

Perpustakaan digital dimulai dengan otomasi perpustakaan dimana fungsifungsi perpustakaan dikerjakan dengan bantuan komputer. Otomasi perpustakaan ini mulai berkembang pada tahun 1980-an. Namun, pada saat itu hanya 
perpustakaan-perpustakaan besar saja yang menerapkan otomasi perpustakaan mengingat biaya investasinya yang begitu besar. Perputakaan digital merupakan sebuah sistem perpustakaan yang menggunakan elektronik dalam menyampaikan informasi dari sumber yang dimiliki dan menggabungkan koleksi-koleksi, layanan dan sumber daya manusia untuk mendukung penuh siklus penciptaan, diseminasi, pemanfaatan dan penyimpanan data informasi, serta pengetahuan dalam format digital yang telah dievaluasi, diatur, diarsip dan disimpan, melalui komputer stand alone, intranet, atau internet (Susanto, 2010: 17).

Buku-buku penunjang yang diberikan ke SMP Pancasila lebih difokuskan pada buku-buku berbasis kearifan lokal Kalimantan Barat. Banyak generasi muda yang sudah mulai melupakan tradisi dan budaya lokal, sehingga memerlukan upaya untuk mengembalikan dan melestarikan budaya lokal. Pertimbangan lain untuk memberikan koleksi buku kearifan lokal dikarenakan kearifan lokal adalah identitas atau kepribadian budaya sebuah bangsa yang menyebabkan bangsa tersebut mampu menyerap, bahkan mengolah kebudayaan yang berasal dari luar atau bangsa lain menjadi watak dan kemampuan sendiri (Wibowo, 2015:17). Pemilihan buku-buku kearifan lokal Kalimantan Barat dikarenakan sekolah sudah memiliki cukup banyak buku-buku umum yang dapat menjadi bahan bacaan siswa akan tetapi sekolah belum memiliki buku-buku kearian lokal Kalimantan Barat yang dapat membuka cakrawala siswa untuk mengetahui beerbagai kearifan lokal di Kalimantan Barat yang sangat beragam.

Dalam kegiatan pengadaan buku berkolaborasi dengan toko buku HA. Pemilihan kolaborator untuk penyediaan buku-buku di SMP Pancasila dikarenakan toko buku HA merupan satu-satunya toko buku di Kalimantan Barat yang hanya menjual buku-buku kearifan lokal Kalimantan Barat maupun bukubuku yang ditulis oleh para penulis dari Kalimantan Barat. Guna menunjang penyediaan buku-buku kearifan lokal Kalimantan Barat, pengabdi berkolaborasi dengan Balai Bahasa Provinsi Kalimantan Barat. Balai Bahasa Provinsi Kalimantan Barat menyediakan banyak buku-buku kearifan lokal baik hasil tulisan tim Balai Bahasa maupun buku hasil karya para guru di lingkungan Kalimantan Barat. 


\section{Manajemen Perpustakaan}

Kegiatan selanjutnya adalah pelatihan manajemen perpustakaan. Pelatihan ini selain untuk pengelola perpustakaan juga untuk guru-guru di SMP Pancasila, karena guru juga harus turut menunjang budaya literasi di sekolah. Kegiatan pelatihan manajemen perpustakaan berkolaborasi dengan perpustakaan IKIP PGRI Pontianak. Manajemen perpustakaan dapat diartikan sebagai suatu proses kegiatan manuasia dan perlengkapan perpustakaan untuk mencapai tujuan dengan efektif dan efisien (Suhardini, 2011:16). Sistem manajemen sangat penting dalam pengelolaan perpustakaan, sehingga perpustakaan dapat dikelola dengan baik tidak semata-mata hanya menjadi ruangan yang tidak digunakan. Karena manajemen perpustakaan sekolah pada dasarnya adalah proses mengoptimalkan kontribusi manusia, material, anggaran untuk mencapai tujuan perpustakaan. Menurut Mansyur (2015:46) manajemen perpustakaan merupakan rangakain terdiri dari planning (perencanaan), organizing (pengorganisasian), staffing (pngaturan staf), directing (pengarahan) dan controling (pengawasan).

Keberhasilan pengelolaan sebuah perpustakan sekolah tidak terlepas dari kolaborasi antara kepala sekolah, komite sekolah, guru, pustakawan dan siswa.Beroperasinya perpustakaan tidak terpelapas dari pran pustakawan. Pustakawan harus memiliki ketrampilan kemampuan berkomunikasi secara posistif, kemampuan memahami kebutuhan penguna, kemampuan bekerja sama, memiliki pengetahuan dan pemahaman mengenai kragaman budaya, memiliki pengetahuan mengenai metodologi pembelajaran dan teori pendidikan, memiliki ketrampilan informasi serta bagaimana menggunakannya, memiliki pengetahuan materi perpustkaan yang membentuk koleksi perpustkaan serta bagaimana mengaksesnya, memiliki pengetahuan mengeani bacaan anak, media dan kebudayaan, memiliki pengetahun serta ketrampilan di bidang manajemen dan pemasaran, memiliki pengetahun serta ketrampilan di bidang teknologi informasi.

Berdasarkan hasil pelatihan didapatkan perubahan pengetahuan dalam pengelolaan perpustakaan. Guna mencapai fugsi dan tujuan perpustkaan, 
perpustakaan haruslah dikelola sesuai dengan standar minimal manajemen perpustakaan dan dalam kerangka kerja kebijakan yang tersusun secara jelas.

\section{Gerakan Literasi Sekolah}

Pada aspek non-fisik pula telah dilakukanlah dua kegiatan. Kegiatan pertama adalah pemberian motivasi minat baca siswa dengan judul kegiatan "Pemberian Motivasi Baca Siswa SMP Pancasila Sungai Kakap" yang dilaksanakan pada tanggal 27 Juli 2019 dengan pemateri adalah Bapak Dedi Ari Asfar dari Balai Bahasa Kalimantan barat, dan bapak Verli Pay Sandi dari Komunitas Kalbar Membaca. Sarasaran peserta kegiatan adalah seluruh siswa SMP Pancasila Sungai Kakap. Memotivasi sebagai rangkaian usaha untuk menyediakan kondisi-kondisi tertentu sehingga mau tidak mau dan ingin melakukan sesuatu, dan apabila dia tidak sukan maka akan beusaha untuk meniadakan atau mengelakkan perasaan tidak suka (Sardiman, 2011: 75).

Pemberian motivasi sangat penting bagi siswa dikarenakan sebelum dilakukan tindakan sosialisasi telah didapatkan hasil motivasi literasi siswa SMP Pancasila yang menunjukkan hasil hasil yang rendah. Berdasarkan hasil tersebut maka diadakan kegaitan pemberian motivasi siswa agar muncul motivasi siswa sehingga lebih tertarik untuk membaca. Perpustakaan yang disediakan terdapat dua jenis yaitu perpustakaan fisik yang menyediakan buku-buku cetak dan perpustakaan digital yang menyediakan buku-buku digital. Penyediaan dua jenis perpustakaan ini untuk memfasilitasi siswa dalam membaca. Siswa dapat membaca buku-buku di perpustakaan secara langsung maupun memanfaatkan $e$ book yang telah tersedia di perpustakaan digital. Selain perpustakaan digital mengikuti perkembangan revolusi industri 4.0 juga buku-buku ini dapat diakses dimana saja dan kapan saja tidak terbatas hanya diakses di sekolah saja. Penyediaan perpustakaan yang mumpuni dan nyaman diharapkan dapat memberikan motivasi kepada siswa untuk memulai budaya literasi baik disekolah maupun dimana saja dan menjadikannya sebagai sebuah kebutuhan.

Kegiatan kedua dilaksanakan pada tanggal 28 Juli 2019 dengan judul "Pengenalan dan Sosialisasi Gerakan Literasi Sekolah (GLS) di SMP Pancasila Sungai Kakap”. Pemateri pada kegiatan ini adalah Bapak Dedi Ari Asfar dan Ibu 
Lynda Kurnia Agustina dari SMP Negeri 2 Pontianak selaku sekolah yang sudah melaksanakan GLS. Dengan hadirnya pihak sekolah yang telah menerapkan GLS harapannya dapat menjadi contoh nyata bagi terlaksananya jugga GLS di SMP Pancasila Sungai Kakap. Sasaran kegiatan sosialisasi dan pengenalan ini ialah guru dan orang tua/wali siswa. Keterlibatan guru sangat penting untuk menunjang tumbuh kembangnya budaya literasi di sekolah. Budaya literasi di sekolah merupakan hasil kerjasama yang apik antara seluruh warga sekolah. Harapan budaya literasi ini akan menjadi nadi siswa di sekolah yang dapat dilakukan dimana saja dan kapan saja, tidak hanya saat pembalajaran berlangsung. Pembelajaran merupakan kegiatan wajib dan menjadi nadi dari sebuah sistem pembelajaran.

Harapan budaya literasi bisa mendarah daging tidak terlepas dari peran orang tua. Orang tua siswa diharapkan dapat menunjang tumbuh-kembang budaya literasi di rumah sehingga budaya literasi tidak terbatas hanya disekolah saja akan tetapi bisa menjadi kebutuhan seseorang dimana saja sehingga akan terwujud long life education. Peserta dalam kegiatan ini cukup antusias, terjadi tanya jawab yang interaktif antara peserta dengan pemateri.

\section{SIMPULAN}

Kegiatan pengabdian yang dilaksanakan dari Juni hingga September 2019 ini telah diperoleh hasil sesuai dengan rencana capaian program. Kegiatan pertama adalah pembenahan perpustakaan baik perpustakaan fisik maupun perpustakaan digital. Kegiatan kedua adalah pemberian motivasi mmbaca untuk siswa dan juga pendampingan gerakan literasi sekolah untuk guru dan orang tua siswa. Kegiatan terakhir adalah pendampingan manajemen perpustakaan untuk mengelola perpustakaan dengan standar yang berlaku.

\section{UCAPAN TERIMA KASIH}

Terimakasih tim pengabdi ucapkan kepada DRPM RISTEKDIKTI atas pendanaan PKM Tahun 2019 dan IKIP PGRI Pontianak yang telah sepenuhnya 
mendukung kegiatan PKM ini. Terimakasih juga kami ucapkan untuk SMP Pancasila yang telah menjadi mitra dalam kegiatan ini.

\section{DAFTAR PUSTAKA}

Mansyur, HM. (2015). Manajemen perpustakaan sekolah. Pustakaloka, 7 (1): 4354.

Mubasyaroh. (2016). Pengaruh perpustakaan bagi peningkatan mutu pendidikan perguruan tinggi. Libraria, 4 (1): 77-104.

Satgas GLS Ditjen Dikdasmen. (2018). Strategi literasi dalam pembelajaran di sekolah menengah pertama (materi penyegaran instruktur kurikulum 2013). Jakarta: Kementerian Pendidikan Dan Kebudayaan.

Suhardini, D. (2011). Peranan manajemen perpustakaan sekolah dalam mendukung tujuan sekolah. EduLib, 1 (1): 11-26.

Susanto, S., E. (2010). Desain dan standar perpustakaan digital. Jurnal Pustakawan Indonesia, 10 (2): 17-23. 